(2) Natural gas burners admitting an ample supply of air should be used.

(3) Gas and air should be regulated so that a flame with a short, well-defined inner cone is produced.

(4) The crucibles should be supported on platinum triangles and kept in well-polished condition.

\section{LABORATORY METHODS FOR ORGANIC NITROGEN AVAILABILITY.}

By C. H. JONES.

Received February 17, 1910.

There is an extensive demand for nitrogen in a form suitable for plant food. This demand has been mainly supplied in the past by nitrate of soda, sulphate of ammonia, and the animal and regetable ammoniates, including dried blood, various tankages, fish scrap, bone meal and cottonseed-meal. These constitute a class which furnish nitrogen to the growing plant in a readily available form.

As a supplement to these high-grade manures there has gradually come into use another group of nitrogen-containing materials including raw and treated leather, peat, tartar pomace, garbage tankage, mora meal, beet and gas-house refuse, and others. Their nitrogen availability is supposed to be considerably less than obtains with the so-called standard ammoniates, the nitrogen being so "locked up," "fixed," "embalmed" or "inert" that decomposition in the soil is a long, slow process. Most fertilizer laws legislate against materials in this class, prohibiting their use unless statement of their presence is made.

It does not follow that because a popular classification puts a material in the inert class, that the material may not, by suitable treatment, be so changed as to merit a place in the readily available nitrogen group. The personal equation must be eliminated and each material allowed to stand on its own merits as measured by careful field and pot experiments. In other words, the true availability of any source of nitrogen for plant food must be eventually determined by the growing plant.

It happens, unfortunately, that field and pot experiments cannot be conducted without extensive equipment, that they are time-consuming, and that the great variation in results under seemingly uniform conditions, with different crops, soils, etc., necessitates repetition if anything like true availability averages are to be secured. This has led to the formulation of short laboratory methods designed to differentiate between ammoniates of high and low crop producing power. A history of suggested methods is beyond the scope of this paper and would be out of place here. ${ }^{1}$

I wish to describe at this time first the alkaline

1 Vt. Station, Rep., 11, 1897, page 160. permanganate method and second the pepsin digestion method as employed in the Vermont Experiment Station laboratory and submit results obtained by their use on fifty-one samples representing many socalled high- and low-grade animal and vegetable ammoniates now on the market.

The Alkaline Permanganate Method.-Weigh out an amount of sample containing 0.045 gram of organic nitrogen and transfer to a $600 \mathrm{cc}$. distillation flask. Add $100 \mathrm{cc}$. of alkaline permanganate solution ( 16 grams of pure potassium permanganate and 150 grams sodium hydroxide dissolved in water. and made to volume of I liter), connect with a condenser to which a receiver containing standard acid has been attached, and digest below the boiling point for 30 minutes. Then boil until $85 \mathrm{cc}$. of the distillate are obtained. If the material shows a tendency to adhere to the sides of the flask, an occasional gentle rotation is necessary during distillation.

Pepsin Digestion Method.-Weigh out an amount of sample containing 0.025 gram of organic nitrogen. With raw materials transfer to a suitable $15^{0-200}$ cc. flask and add $100 \mathrm{cc}$. of a pepsin-hydrochloric acid solution. Digest for 24 hours in a water bath at a constant temperature of $40^{\circ} \mathrm{C}$., keeping flasks loosely corked. At the end of the 2 nd, 5 th, 8 th, and I th hours, add $2 \mathrm{cc}$. of ro per cent. hydrochloric acid solution. Shake well after each acid addition. After the digestion filter the contents of the flask through single filters and wash until filtrate amounts to $400 \mathrm{cc}$. Dry and determine nitrogen in the residue by the Kjeldahl or Gunning method.

With commercial fertilizers weigh the required amount on a filter, wash with about $200 \mathrm{cc}$. water, and treat residue as already described.

The pepsin-hydrochloric acid solution is prepared by dissolving 5 grams of the Armour \& Co. soluble scale pepsin ( $r: 3000$ U. S. P.) in $1000 \mathrm{cc}$. of twotenths per cent. hydrochloric acid.

In using this permanganate method with commercial fertilizers it is necessary that the nitrogen present as ammonia and as organic nitrogen be first determined. The amount of material taken is based on the percentage of organic nitrogen present. Nitrates are unaffected by the treatment, and any ammonia orginally present in the sample is deducted from the result obtained before calculating the organic availability. Both nitrates and ammonia are given due credit under the total availability column.

In testing the availability of commercial fertilizers, particularly when ammonia salts are present, it is recommended that the water-insoluble organic nitrogen be determined. An amount of material equivalent to 0.045 gram of water-insoluble organic nitrogen is then weighed onto a hardened filter, washed with about $200 \mathrm{cc}$. of water (small portions at a time), the residue dried at about $90^{\circ} \mathrm{C}$. and transferred from the filter 
into the distillation flask. Permanganate solution is then added and the distillation continued as usual.

The alkaline permanganate method has been used on every sample of officially collected commercial fertilizer analyzed in Vermont since I898. By its use we have noted many variations in nitrogen source from year to year in standard brands, due to changes in company management and other causes. A comparison of the results by both company averages and on individual samples during this interval of 12 years is a long but exceedingly interesting study in itself. Such results as run below 50 per cent. by the permanganate method are tested by the pepsin method outlined above for a further insight as to the nature of the organic nitrogen present.

This permanganate method has been criticized chiefly in that it fails to do justice to cottonseed meal and that concordant results are not obtained by different analysts. The first objection is admitted and the reasons therefor have been elsewhere explained. ${ }^{1}$ Inasmuch, however, as in certain sections cottonseed meal rarely, if ever, appears in commercial fertilizers, and knowing that the time-honored pepsin method does ample justice to this and similar vegetable ammoniates, it should not exempt the local use of the alkaline permanganate method if circumstances warrant. Concerning the second objection, the writer would state that from an experience covering twelve years he is convinced that non-agreement over certain limits is due primarily to details of manipulation. In this laboratory upright condensers are used and the end of the condensing tube does not dip into the standard acid. Working with commercial fertilizers our variation $b \leq t w e \in \mathbf{n}$ parallels is usually not to exceed 0 . Io per cent. nitrogen, equivalent to an arailability of about 2 per cent. With certain concentrates the variation may run a little higher but a few duplications will soon afford a satisfactory average. It should be remembered that we are not comparing availability differences of from 2 to 4 per cent. Thus, if two different brands show availabilities of 64 and 66 per cent., respectively, they both rank equally well, but if one shows 40 per cent. and the other 66 . per cent., the former is tested by the pepsin method as well as qualitatively, to show the nature of the nitrogen scource more in detail.

Let me illustrate by giving a few actual figures taken from recent inspections:

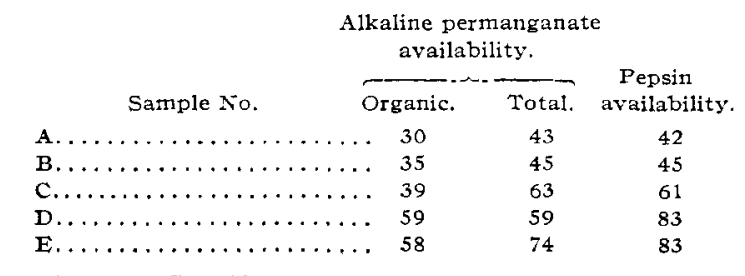

1 Vt. Exp. Sta., Rep. 12, 1898, page 139.
The organic nitrogen in samples $A$ and $B$ is certainly open to question. Sample $C$ is somewhat better, while $\mathrm{D}$ and $\mathrm{E}$ are all that could be desired.

The following tables show the results obtained by the alkaline permanganate and pepsin methods on fifty-one samples of animal and vegetable ammoniates.

Briefly reviewing the results as summarized in Table II, we have in the first group the probably readily available ammoniates. Excepting the three vegetable ammoniates to which the alkaline permanganate method is not applicable, but whose rank is clearly established by the pepsin figure, we find the permanganate availability running from 56 to 68 and the pepsin from 71 to 97 per cent. It should be noted that the pepsin treatment gives a low result, 25 per cent., for hoof meal, against 66 per cent. by the permanganate process. Certain vegetation tests indicate that the higher figure is possibly more nearly correct. $^{2}$

The second group, whether of vegetable or animal origin, shows a decided drop in availability percentage by both methods and fall into the questionable class. The leather preparations were mechanically very fine and dry and in many instances partially soluble in water. Many of them carried a considerable percentage of ammonia, for which credit is given in the column headed "total."

The inert nature of the nitrogen in peat is well recognized. Note the low permanganate availability of 27 per cent. and the pepsin figure of -25 per cent. This negative result indicates that an insoluble nitrogen figure of 125 per cent. was obtained by the pepsin treatment being occasioned by an absorption of nitrogen from the pepsin solution during digestion, which the subsequent washing failed to remove.

Without going into further detail, it seems fair to conclude that the methods are capable of making fairly broad distinctions between ammoniates of presumably high and low nitrogen availability. The former is simple and rapid and very useful as an indicative method, in that it will eliminate quickly such samples as would doubtless rank well by the longer pepsin process or by field and pot experiments.

In addition to the above results, we have previously published data ${ }^{2}$ showing the organic nitrogen availability by the alkaline permanganate method on sixty one animal and vegetable ammoniates. Applied to commercial fertilizers, the method has indicated that the organic nitrogen they contained was derived from good sources in a large majority of cases, the range in availability during the past 12 years for company averages being from 34 to 77 per cent.

1 Conn. (State) Agr. Exp. Sta., Rpts. 18 (1894), pp. 95-100; 19 (1895), p. 112; 20 (1896), pp. 189-190; 21 (1897), p. 270.

2 Vt. Exp. Sta., Rep. 14, 1900, page 221 
Table I.-Alkaline Permanganate and Pepsin Avallabilities.

\begin{tabular}{|c|c|c|c|c|c|c|c|c|}
\hline \multirow[b]{2}{*}{ No. } & \multirow{2}{*}{ Material. } & \multicolumn{3}{|c|}{ Nitrogen content. } & \multirow[b]{2}{*}{$\begin{array}{l}\text { Grams, } \\
\text { used. }\end{array}$} & \multicolumn{2}{|c|}{$\begin{array}{l}\text { Alkaline perman. } \\
\text { ganate avallability. }\end{array}$} & \multirow{2}{*}{$\begin{array}{l}\text { Pepsin } \\
\text { avail- } \\
\text { ability, } \\
\text { pet cent. }\end{array}$} \\
\hline & & $\begin{array}{l}\text { Total, } \\
\text { per cent. }\end{array}$ & $\begin{array}{l}\text { Ammonia, } \\
\text { per cent }\end{array}$ & $\begin{array}{l}\text { Organic, } \\
\text { per cent. }\end{array}$ & & $\begin{array}{l}\text { Organic, } \\
\text { per cent. }\end{array}$ & $\begin{array}{l}\text { Total, } \\
\text { per cent. }\end{array}$ & \\
\hline 1 & 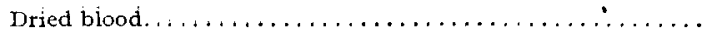 & 13.79 & 0.07 & 13.79 & 0.33 & $66 \quad$ & . 66 & 93 \\
\hline 2 & 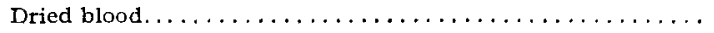 & 14.63 & $\ldots$ & 14.63 & 0.31 & 67 & 67 & 97 \\
\hline 3 & 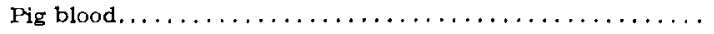 & 13.54 & 0.68 & 12.86 & 0.35 & 64 & 66 & 98 \\
\hline 4 & 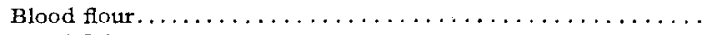 & 14.03 & $\ldots$ & 14.03 & 0.32 & 62 & 62 & 98 \\
\hline 5 & 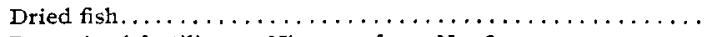 & 6.93 & $\ldots$ & 6.93 & 0.67 & 68 & 68 & 77 \\
\hline 6 & Dry mixed fertilizer. Nitrogen from No. $2, \ldots \ldots \ldots \ldots \ldots$ & 4.15 & $\ldots$ & 4.15 & 1.08 & 69 & 69 & 95 \\
\hline 7 & Tankage, high-grade $\ldots \ldots \ldots \ldots \ldots \ldots \ldots \ldots \ldots$ & 10.23 & 0.07 & 10.23 & 0.44 & 57 & 57 & 79 \\
\hline 8 & 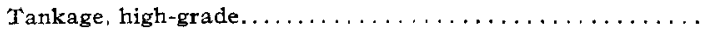 & 9.78 & 0.07 & 9.78 & 0.46 & 59 & 59 & 77 \\
\hline 9 & 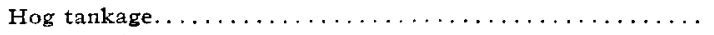 & 5.63 & $\ldots$ & 5.63 & 0.80 & 52 & 52 & 58 \\
\hline 10 & 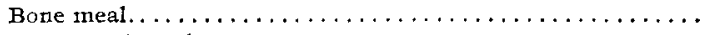 & 2.66 & $\ldots$ & 2.66 & 1.69 & 56 & 56 & 75 \\
\hline 11 & 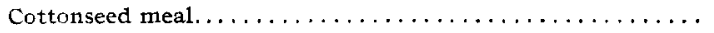 & 6.40 & $\ldots$ & 6.40 & 0.70 & 46 & 46 & 88 \\
\hline 12 & Castor pomace $\ldots \ldots \ldots \ldots \ldots \ldots \ldots \ldots \ldots \ldots \ldots \ldots \ldots \ldots$ & 4.83 & 0.32 & 4.51 & 0.98 & 46 & 50 & 78 \\
\hline 13 & 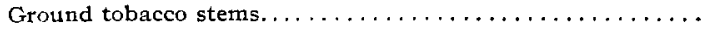 & 1.65 & $\ldots$ & 1.65 & 2.73 & 12 & 12 & 63 \\
\hline 14 & Scotch $i:$ de and hoof meal $\ldots \ldots \ldots \ldots \ldots \ldots$ & 14.80 & 0.14 & 14,80 & 0.30 & 64 & 64 & 21 \\
\hline 15 & 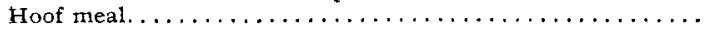 & 15.15 & 0.28 & $1+.87$ & 0.30 & 68 & 69 & 28 \\
\hline 26 & Treated leather, foreign..$\ldots \ldots \ldots \ldots \ldots \ldots \ldots \ldots \ldots$ & 8.67 & 0.07 & 8.67 & 0.52 & 41 & 41 & 41 \\
\hline 17 & 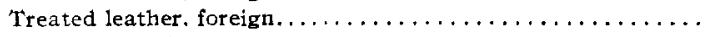 & 8.09 & 0.07 & 8.09 & 0.56 & 44 & 44 & 47 \\
\hline 18 & 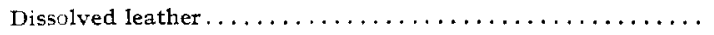 & 8.25 & 1.09 & 7.16 & 0.63 & 43 & 51 & 47 \\
\hline 19 & 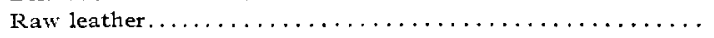 & 8.00 & $\ldots$ & 8.00 & 0.56 & 40 & 40 & 53 \\
\hline 20 & 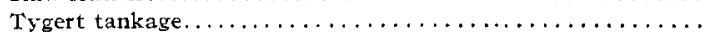 & 9,58 & 0.07 & 9.58 & 0.47 & 52 & 52 & 43 \\
\hline 21 & Solubilized organic nitrogen $\ldots \ldots \ldots \ldots \ldots \ldots \ldots \ldots$ & 7.55 & 0.25 & 7.30 & 0.62 & 48 & 49 & 55 \\
\hline 22 & Solubilized organic nitrogen,$\ldots \ldots \ldots \ldots \ldots \ldots \ldots$ & 6.58 & 0.14 & 6.44 & 0.70 & 45 & 46 & 60 \\
\hline 23 & Orighal nitrogenous manure $\ldots \ldots \ldots \ldots \ldots \ldots \ldots$ & 7.62 & 0.41 & 7.21 & 0.62 & 43 & 46 & 49 \\
\hline 24 & Ammoniated manure $\ldots \ldots \ldots \ldots \ldots \ldots \ldots \ldots \ldots \ldots$ & 8.03 & 1.04 & 6.99 & 0.64 & 43 & $5 !$ & 42 \\
\hline 25 & Nitrogenous manure $\ldots \ldots \ldots \ldots \ldots \ldots \ldots \ldots \ldots \ldots \ldots \ldots \ldots$ & 6.75 & 0.14 & 6.61 & 0.68 & 46 & 47 & 65 \\
\hline 26 & Niţrogenous manure $\ldots \ldots \ldots \ldots \ldots \ldots \ldots \ldots \ldots \ldots$ & 6.97 & 0.44 & 6,53 & 0.69 & 49 & 52 & 39 \\
\hline 27 & 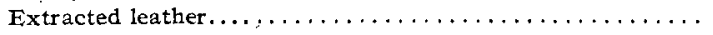 & 8.21 & $\ldots$ & 8.21 & 0.55 & 37 & 37 & 45 \\
\hline 28 & 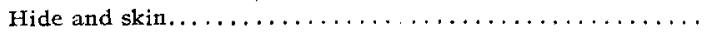 & 7.83 & $\ldots$ & 7.83 & 0.58 & 44 & 44 & 44 \\
\hline 29 & 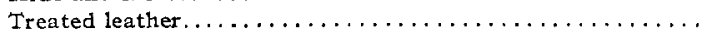 & 7.39 & 0.10 & 7.39 & 0.61 & 45 & 45 & 46 \\
\hline 30 & 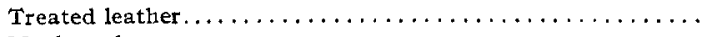 & 7.13 & 0.14 & 6.99 & 0.64 & 46 & 48 & 63 \\
\hline 31 & 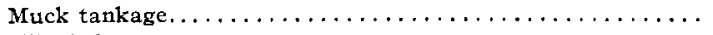 & 2.86 & $\ldots$ & 2.86 & 1.57 & 30 & 30 & -12 \\
\hline 32 & Illinois humus peat. $\ldots \ldots \ldots \ldots \ldots \ldots \ldots \ldots \ldots \ldots \ldots$ & 2.83 & $\ldots$ & 2.83 & 1.59 & 33 & 33 & -22 \\
\hline 33 & Nitrogenous material, $G \ldots \ldots \ldots \ldots \ldots \ldots \ldots \ldots \ldots$ & 3.13 & $\ldots$ & 3.13 & 1.44 & 31 & 31 & -5 \\
\hline 34 & Kiln-dried peat, Florida $\ldots \ldots \ldots \ldots \ldots \ldots \ldots \ldots \ldots$ & 2.12 & $\ldots$ & 2.12 & 2.12 & 23 & 23 & -36 \\
\hline 35 & Air-dried peat, Florida $\ldots \ldots \ldots \ldots \ldots \ldots \ldots \ldots \ldots$ & 2.07 & $\ldots$ & 2.07 & 2.17 & 23 & 23 & -37 \\
\hline 36 & 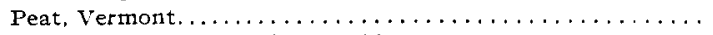 & 1.68 & $\ldots$ & 1.68 & 2.68 & 23 & 2.3 & -25 \\
\hline 37 & 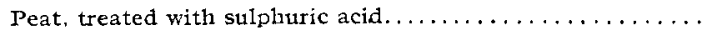 & 0.55 & $\ldots$ & 0.55 & 8.18 & 36 & 36 & 19 \\
\hline 38 & 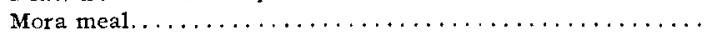 & 2.67 & $\ldots$ & 2.67 & 1.69 & 26 & 26 & 46 \\
\hline 39 & 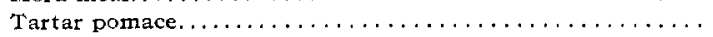 & 4.23 & 0.23 & 4.00 & 1.13 & 22 & 26 & 12 \\
\hline 40 & 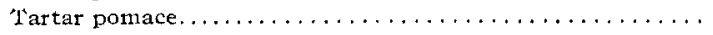 & 3.72 & 0.28 & 3.44 & 1.31 & 26 & 31 & 3 \\
\hline 41 & 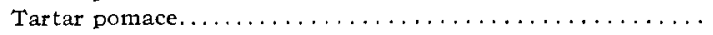 & 4.54 & 0.37 & 4.17 & 1.08 & 43 & 47 & 29 \\
\hline 42 & 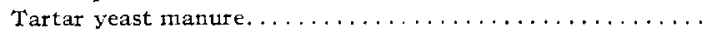 & 3.74 & 0.27 & 3.47 & 1.30 & 32 & 37 & 6 \\
\hline 43 & Tartar yeast mixture $\ldots \ldots \ldots \ldots \ldots \ldots \ldots \ldots \ldots \ldots \ldots \ldots \ldots \ldots$ & 6.51 & 0.34 & 6.17 & 0.73 & 39 & 42 & 36 \\
\hline 44 & 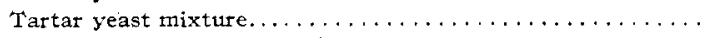 & 4.92 & 0.25 & 4.67 & 0.96 & 37 & 41 & 31 \\
\hline 45 & Garbage tatıkage, New York $\ldots \ldots \ldots \ldots \ldots \ldots \ldots \ldots$ & 2.10 & $\ldots$ & 2,10 & 2.14 & 21 & 21 & 6 \\
\hline 46 & 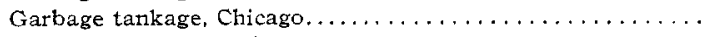 & 2.26 & $\ldots$ & 2.26 & 1.99 & 23 & 23 & 35 \\
\hline 47 & 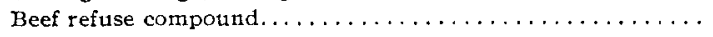 & 7.32 & 2.7 .7 & 4.55 & 0.99 & 15 & 47 & 22 \\
\hline 48 & 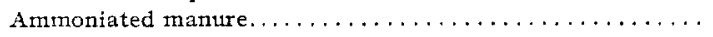 & 6.18 & 0.97 & 5.21 & 0.86 & 34 & 44 & 23 \\
\hline 49 & 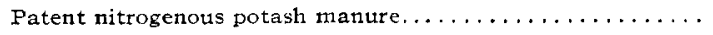 & 6.33 & 1.53 & 4.80 & 0.94 & 15 & 35 & 12 \\
\hline 50 & 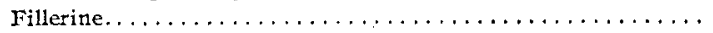 & 6.28 & 1.89 & 4.39 & 1.03 & 18 & 43 & 14 \\
\hline 51 & 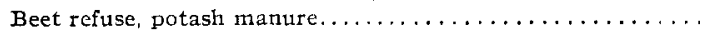 & 4.47 & 0.14 & 4.33 & 1.04 & 29 & $3 !$ & 43 \\
\hline
\end{tabular}

Table II.-Avajlability Summary.

Average alkaline permanganate availability.

Material.

Organic, Total. $\begin{gathered}\text { Average } \\ \text { pépsin } \\ \text { availa- }\end{gathered}$

$\begin{array}{ll}65 & 97 \\ 68 & 77 \\ 56 & 71 \\ 56 & 75 \\ 46 & 88 \\ 50 & 78 \\ 12 & 63 \\ 67 & 25 \\ 45 & 49 \\ 27 & -23 \\ 26 & 46 \\ 37 & 20 \\ 22 & 20 \\ 42 & 19 \\ 43 & 14 \\ 31 & 43\end{array}$

The latter figure indicates a good grade of material and the former a decidedly poor grade, so much so that steps were taken to see that better materials were used.
The writer recently treated a portion of sample No. 36 with sulphuric acid, allowed the mixture to stand for 3 days on a steam radiator and then neutralized the excess acid with carbonate of lime. The resulting material was dried and ground and is listed in Table I as No. 37. Comparing results, we note that the original peat, which by the way is a composite from 35 samples representing the deposits in Chittenden County, Vermont, shows an availability of 23 by permanganate and -25 by pepsin, while the sulphuric acid-treated residue gave $3^{6}$ and +19 , a gain in availability measured by the permanganate and pepsin methods of 13 and 44 per cent., respectively.

Four of the samples listed in Table I have been recently tested by pot experiments at R. I. Experiment Station. The results as furnished by Dr. Hartwell, together with our results by the permanganate and pepsin methods, are stated below: 


\begin{tabular}{|c|c|c|c|c|c|c|}
\hline \multirow{3}{*}{$\begin{array}{c}\text { Sample } \\
\text { No. }\end{array}$} & \multicolumn{5}{|c|}{ Availability by: } & \multirow{3}{*}{$\begin{array}{l}\text { Pepsin } \\
\text { method. }\end{array}$} \\
\hline & \multicolumn{3}{|c|}{ Pot experiment. } & \multicolumn{2}{|c|}{$\begin{array}{l}\text { Alkaline per- } \\
\text { manganate method. }\end{array}$} & \\
\hline & Barley. & Millet. & Oats. & Organic. & Total. & \\
\hline 23. & 52 & 70 & 62 & 43 & 46 & 49 \\
\hline $27 .$. & 10 & 49 & 38 & 37 & $37^{\circ}$ & 45 \\
\hline 42 . & 19 & 0 & 38 & 32 & 37 & 6 \\
\hline $49 \ldots$ & 34 & 39 & 21 & 15 & 35 & 12 \\
\hline
\end{tabular}

Without discussing the results and variations therein, it is sufficient to observe that both the permanganate and pepsin methods clearly agree as to the superiority of sample 23 , and are in accord with the results by pot experiment.

The writer has found it useful in interpreting availability figures secured by laboratory methods to determine the ratio between organic nitrogen and the organic matter present, in both crude stock and fertilizers.

The testing of crude nitrogenous stock by field or pot experiments will, of course, show their availability when used alone or in dry mixed goods. Another factor is introduced when these materials are used in so termed wet mixed goods. The organic nitrogen is here subjected to a sulphuric acid treatment and considerable heat is produced which, judging from analogy with the results by the Kjeldahi nitrogen process, cannot decrease the availability.

It is impossible to duplicate the manufacturing process on a small scale in the laboratory, although the use of a fireless cooker after the addition of sulphuric acid has been suggested. To settle this interesting point it will be necessary for the manufacturer to work with parties who are so situated that they can conduct availability experiments, at least to the extent of furnishing suitable quantities of authentic samples of the various questionable nitrogen-containing materials, before and after the sulphuric acid treatment.

The writer clearly realizes that both the methods outlined are empirical and far from perfect, but believes it nevertheless true that by their use the majority of goods of unquestionable excellence as to nitrogen availability may be quickly and positively eliminated, leaving a relatively small number for more elaborate examination.

VERMONT EXPERTMENT STATION,

Burlington, Vermont.

\section{THE DETECTION OF INFERIOR AMMONIATES IN COMMERCIAL FERTILIZERS.}

By JoHN Phillips STreet.

Received February 17, 1910.

It is a recognized fact that the use of a filler in commercial fertilizers is often necessary and at times even desirable if a dry and friable fertilizer is to be obtained that will not clog on drilling. When a filler is used for this purpose alone there is no legitimate objection to its use, provided that the claimed com- position of the fertilizer is maintained and provided that the use of fillers does not encourage to too great a degree the manufacture of low-grade mixed fertilizers, which are always a relatively expensive form of plant food for the farmer.

In recent years, however, the subject of fillers has taken a different aspect. It has been found that dried peat is an admirable absorbent and that its use in a fertilizer generally assures excellent mechanical condition. Fortunately, or unfortunately, dried peat contains a considerable percentage of nitrogen, often over 3 per cent., which repeated experiments have shown to be exceedingly inert. The use of such a nitrogen-bearing filler in compounding mixed fertilizers has given the agricultural chemist much difficulty in interpreting his results, especially when by the policy of the fertilizer control of his state he is expected to affix a commercial valuation to the mixture. No one will argue that dried peat should receive the same valuation as blood, high-grade tankage, fish, bone or cottonseed-meal. Accordingly, it is incumbent upon the chemist to devise some method whereby this inferior form may be differentiated from those whose value is unquestioned. The manufacturers claim that the amount of peat used seldom exceeds 200 or $300 \mathrm{lbs}$. per ton. In a high-grade fertilizer, guaranteeing 4 or 5 per cent. of ammonia, it is admitted that the introduction of this relatively small amount of peat is without great practical significance. But in the case of the numerous class of fertilizers, carrying a guaranty of I per cent. ammonia, the problem is quite different, for here the peat nitrogen may easily make up one-half of the total nitrogen, a condition which $I$ found in at least one brand during my last inspection.

Various methods have been suggested for the detection of peat in mixtures, the microscope, the various permanganate of potash methods and the pentosan method of the writer. In a dry-mixed fertilizer the microscope is of undoubted value in the detection of peat, but where the wet-mixing process has been employed it is far more reliable. The alkaline permanganate method of Jones has given excellent results in the hands of some chemists, but personally I have never been able to control conditions so as to warrant uniform determinations made at different times with this method. The neutral permanganate method suggested by the writer some years ago has given excellent results with raw materials, clearly distinguishing between high-grade and inferior ammoniates. When applied to mixed fertilizers, however, the details of manipulation hitherto given with the method fail to furnish any sharp line of demarcation between the good and the bad. The pentosan method, likewise suggested by myself, is too local in its application to be of much practical value. In states like my own, Connecticut, where immense 